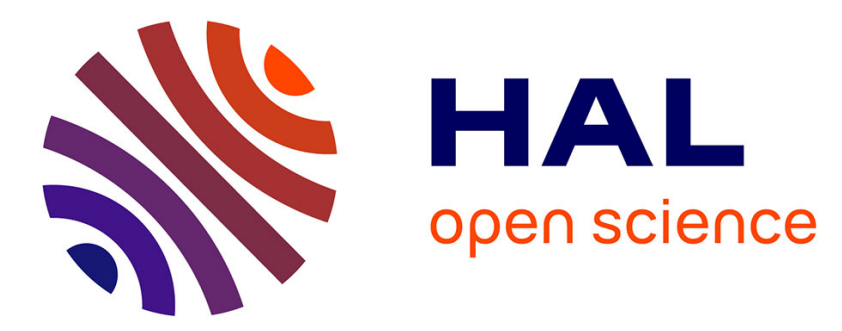

\title{
Phenolic compounds content in Pinus halepensis Mill. needles: a bioindicator of air pollution
}

Vanina Pasqualini, Christine Robles, Suzanne Garzino, Stephane Greff, Anne Bousquet-Mélou, Gilles Bonin

\section{- To cite this version:}

Vanina Pasqualini, Christine Robles, Suzanne Garzino, Stephane Greff, Anne Bousquet-Mélou, et al. Phenolic compounds content in Pinus halepensis Mill. needles: a bioindicator of air pollution. Chemosphere, 2003, 52 (1), pp.239 - 248. 10.1016/S0045-6535(03)00268-6 . hal-01764124

\section{HAL Id: hal-01764124 \\ https://hal-amu.archives-ouvertes.fr/hal-01764124}

Submitted on 11 Apr 2018

HAL is a multi-disciplinary open access archive for the deposit and dissemination of scientific research documents, whether they are published or not. The documents may come from teaching and research institutions in France or abroad, or from public or private research centers.
L'archive ouverte pluridisciplinaire HAL, est destinée au dépôt et à la diffusion de documents scientifiques de niveau recherche, publiés ou non, émanant des établissements d'enseignement et de recherche français ou étrangers, des laboratoires publics ou privés. 


\title{
Phenolic compounds content in Pinus halepensis Mill. needles: a bioindicator of air pollution
}

\author{
V. Pasqualini ${ }^{\text {a,* }}$, C. Robles ${ }^{\text {b }}$, S. Garzino ${ }^{\text {b }}$, S. Greff ${ }^{\text {b }}$, \\ A. Bousquet-Melou ${ }^{\mathrm{b}}$, G. Bonin ${ }^{\mathrm{b}}$ \\ a Faculté des Sciences et Techniques, Université de Corse, Equipe Ecosystèmes littoraux, \\ B.P. 52, 20250 Corte, France \\ ${ }^{\mathrm{b}}$ Institut Méditerranéen d'Ecologie et Paléoécologie-UMR CNRS 6116, Laboratoire de Biosystématique et \\ d'Ecologie Méditerranéenne, Université de Provence, Case 421 bis, Avenue Escadrille Normandie Niemen, \\ 13397 Marseille, Cedex 20, France
}

\begin{abstract}
Foliar phenol concentrations (total and simple phenols) were determined in Aleppo pine (Pinus halepensis Mill.) needles collected in June 2000, from 6 sites affected by various forms of atmospheric pollutants $\left(\mathrm{NO}, \mathrm{NO}_{2}, \mathrm{NO}_{x}, \mathrm{O}_{3}\right.$ and $\mathrm{SO}_{2}$ ) monitored during two months. Results show an increase in total phenol content with exposure to sulphur dioxide and a reduction with exposure to nitrogen oxide pollution. $p$-Coumaric acid, syringic acid and 4-hydroxybenzoic acid concentrations increase with exposure to nitrogen oxide pollution, whereas gallic acid and vanillin decrease in the presence respectively of sulphur dioxide and ozone. This in situ work confirms the major interest of using total and simple phenolic compounds of $P$. halepensis as biological indicators of air quality.
\end{abstract}

Keywords: Total phenolics; Simple phenolics; Air pollution; Aleppo pine

\section{Introduction}

The increasing development of human activities has given rise to a significant increase in atmospheric pollutants which may have an impact on human health, as for example the increase of the blood pressure (IbaldMulli et al., 2001). The impact of air pollutants on human health varies according to their air concentration and inhalated quantity. Pollution levels have to be controlled. Awareness of this environmental problem has led to the setting up of numerous organizations specializing in air quality control (Bortnick and Stetzer, 2002). While air quality is now regularly monitored in

\footnotetext{
* Corresponding author. Tel.: +33-4-95-45-00-55; fax: +33-495-46-24-41.

E-mail address: pasquali@univ-corse.fr (V. Pasqualini).
}

some exposed areas, the impact of these various atmospheric pollutants on living organisms remains a poorly known phenomenon. The use of plant bioindicators has proved to be a complementary method of investigation for pollutant analysis, insofar as they constitute real biological integrators, capable of providing a basis for assessment of environmental quality and/or contamination (Hawksworth and Rose, 1970; Howell, 1970; Seaward, 1993; Monna et al., 1999; Alaimo et al., 2000; Conti and Cecchetti, 2001; Omasa et al., 2002). Over the past few years, research has focused on the measurement of chemical compounds in plants, as indicators of a particular environment state. This provides a basis for determining the long-term impact of even low levels of pollution and, because these physiological changes appear before morphological and anatomical symptoms, they provide an early warning signal of modifications in environmental quality. 
Among the chemical compounds in plants, secondary metabolites are of great importance in plant-environment relationships (Beart et al., 1985; Hagerman and Robbins, 1987; Haslam, 1989; Rhodes, 1994; Waterman and Mole, 1994; White, 1994; Macheix, 1996; Spaink, 1998). Among these secondary metabolites, phenolic compounds are of particular interest because of (i) their major ecological role in allelopathic processes (Haslam, 1989; Rhodes, 1994; Cooper-Driver and Bhattacharya, 1998), (ii) their role in the protection of plants against herbivores (Pisani and Distel, 1998) and (iii) their involvement in the response of plants to environmental stress such as intra and/or interspecific competition or atmospheric pollution (Muzika, 1993; Karolewski and Giertych, 1994; Peñuelas et al., 1996). Most bibliographical studies on the impact of atmospheric pollutants on phenolic compounds only concerns the impact of standard atmospheric pollutants under controlled experimental conditions (Karolewski, 1990; Giertych and Karolewski, 1993; Karolewski and Giertych, 1994; Peñuelas et al., 1996). Studies carried out under natural conditions are rare (Karolewski and Giertych, 1995; Loponen et al., 2001) and often concern only ozone impact (Karlsson et al., 1995; Chappelka et al., 1999; Oleksyn et al., 1999). In addition, with the exception of a recent study on a species of the genus Betula (Loponen et al., 2001), bibliographical surveys have only presented data on total phenol content. However, the validation of a bioindicator requires the undertaking of experiments under natural conditions in order to check whether, in situ, other environmental factors do not mask the potential bioindicator's response to the disturbance which one seeks to measure.
The aim of this study was to measure phenolics concentrations (total and simple phenolics) in Aleppo pine needles (Pinus halepensis Mill) located in several areas exposed to the influence of various atmospheric pollutants, in order to determine the combined impact of these pollutants on phenolic compound concentrations. $P$. halepensis was chosen for this study because it is a widespread Mediterranean tree and has the advantage of growing both in urban and natural sites. The Berre lagoon area near Marseille (Provence, South of France) was selected as the experimental site because of its high concentration of business and industrial activity. In a human health purpose, a further aim of this research is to assess whether total and simple phenol concentrations in $P$. halepensis needles can constitute reliable bioindicators of air quality.

\section{Material and methods}

\subsection{Study sites and sampling protocol}

The sampling program for $P$. halepensis needles was realized on 21 June 2000, at seven study sites (1: Rognac; 2: Sausset-les-pins; 3: Martigues; 4: Port de Bouc; 5: St. Martin de Crau; 6: St. Rémy of Provence; 7: Luberon) located in the Etang de Berre area (Fig. 1). These study sites have been chosen according to their air pollutants levels measured in 1998/1999 (AIRFOBEP, 2000). They have different levels of air pollution. For each station, the age of trees was determined beforehand by means of a Pressler drill. To avoid age-related variations, only specimens of about thirty years of age were sampled.

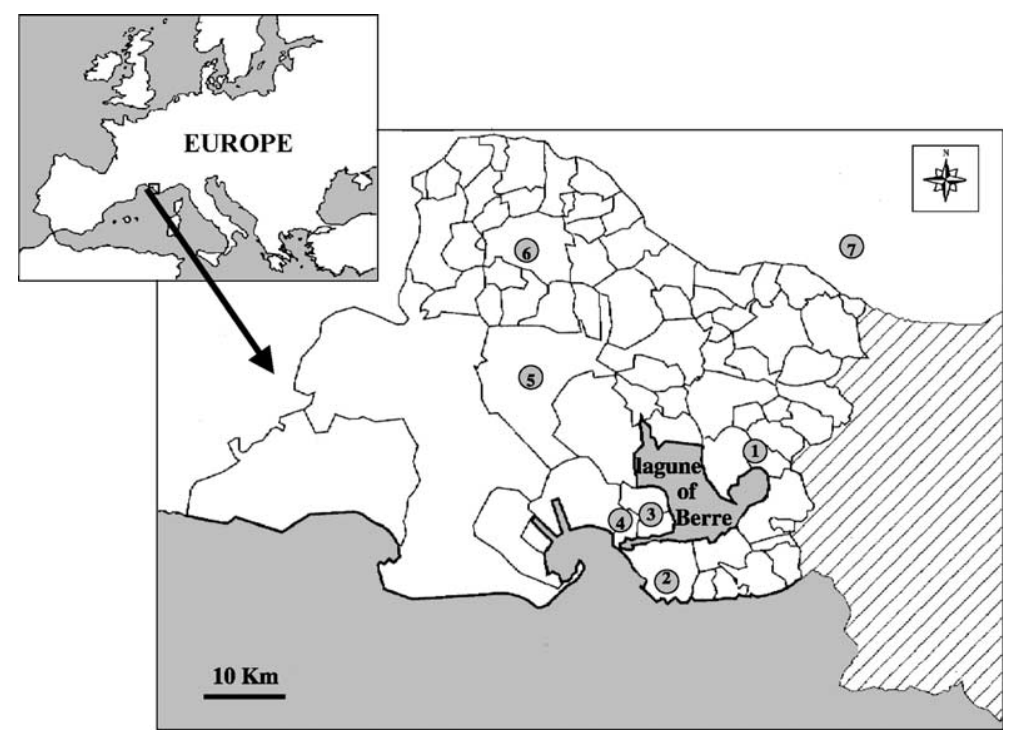

Fig. 1. Localization of the study sites. 
On these thirty years old trees, six Pine specimens were taken at random in order to have a sufficient number of replicates to perform statistical tests. On each tree, oneyear-old needles (1999 shoots) were collected at all canopy levels. The needles were then oven-dried at $40{ }^{\circ} \mathrm{C}$ during one week. They were then fragmented in small pieces for total phenol concentration analysis or crushed using a mixer for simple phenol concentration analysis. Needles (or needle powder) were stored in the dark at room temperature.

\subsection{Atmospheric pollutants}

Since industrial activity and road traffic representing the most significant sources of air pollution in this area, five pollutants were considered in this study: nitric oxide (NO), nitrogen dioxide $\left(\mathrm{NO}_{2}\right)$, nitrogen oxides $\left(\mathrm{NO}_{x}\right.$; nitric oxide and dioxide not included), sulphur dioxide $\left(\mathrm{SO}_{2}\right)$ and ozone $\left(\mathrm{O}_{3}\right)$. Each air pollutant was measured according a reference method (AIRFOBEP, 2000). Concentrations of each atmospheric pollutant were monitored four times per hour, for each station, during the period from 20 April 2000 to 20 June 2000, by AIRFOBEP, the organization responsible for air quality monitoring in this area (Thieleke, Personal communication: Table 1).

\subsection{Total phenols}

The method of extraction of total phenolics was based on the work of Peñuelas et al. (1996). One gram per sample of dry needles was extracted with $20 \mathrm{ml}$ of $70 \%$ aqueous methanol (v/v) acidified with some concentrated $\mathrm{HCl}$ drops. The mixture was left at room temperature during one hour and a half. Total phenol quantification was achieved by colorimetric reaction with Folin-Ciocalteu reagent. After $1 \mathrm{~h}$, the reaction was completed and measured at $720 \mathrm{~nm}$ on a Phillips PU 8620 spectrophotometer. Quantitative results were expressed with reference to gallic acid.

\subsection{Simple phenols}

The extraction protocol and analysis of simple phenols were based on the method described by Souto et al.
(1994). Hundred milliliters of a 70\% aqueous methanol (v/v), acidified by some concentrated $\mathrm{HCl}$ drops, were added to $5 \mathrm{~g}$ of Aleppo pine needle powder. After being shaken for $2 \mathrm{~h}$ at room temperature and filtered on Whatman paper, the methanol was evaporated under reduced pressure. The resulting aqueous solution was then extracted three times with $30 \mathrm{ml}$ of diethyl ether. The ethered fractions were combined and evaporated to dryness. The residue was dissolved in $2 \mathrm{ml}$ methanol. The mixture was purified on SPE LC-18 cartridge and analysed by High Performance Liquid Chromatography (HPLC; Hewlett Packard ${ }^{\circledR}$ series 1050 equipped with a diode-array detector). The column used was $5 \mu \mathrm{m} \mathrm{Nu}$ cleosil $100 \mathrm{C} 18$ column $(4 \times 250 \mathrm{~mm})$. The injection volume was $10 \mu \mathrm{l}$, the constant flow rate was $0.8 \mathrm{ml} / \mathrm{min}$. The eluent composition was: A-water/phosphoric acid (pH 3,4); B-methanol/phosphoric acid ( $\mathrm{pH} \mathrm{3,4).} \mathrm{The}$ elution profile was: $0-35 \mathrm{~min}, 0-10 \% \mathrm{~B}$ (linear gradient); 35-75 min, 10\% B (isocratic); 75-120 min, 10-30\% B (linear gradient); $120-150 \mathrm{~min}, 30 \% \mathrm{~B}$ (isocratic). Identification of phenolic compounds was based on the comparison of their retention time and their UV spectra $(210-400 \mathrm{~nm})$ with those of commercial standards $\left(\right.$ Sigma-Aldrich ${ }^{\circledR}$ ). For the quantification of compounds, the detection wavelength was $270 \mathrm{~nm}$.

\subsection{Statistical analysis}

Statistical data processing was performed on Statview $^{\circledR}$ and Statitcf ${ }^{\circledR}$ software. The limit of significance of the various tests was $P \leqslant 0.05$. To compare the concentrations in atmospheric pollutants between the various sites, a factorial plane Anova was performed from daily averages of each pollutant. In order to compare total phenol content between the various sites, a non-parametric Kruskal-Wallis test was performed. A matrix of correlation was made from simple and total phenol concentrations and concentrations of each pollutant in the various sites in order to evaluate significant statistical relationships between these data groups. Two principal component analyses (PCA) were performed on the basis of all of the data. A first PCA was performed with total phenol and atmospheric pollutant concentrations: 42 points (6 individuals, 7 stations) and 6 variables. The

Table 1

Contents of atmospheric pollutants at the sites $\left(\mu \mathrm{g} / \mathrm{m}^{3}\right)$

\begin{tabular}{lccrrr}
\hline Sites & $\mathrm{NO}$ & $\mathrm{NO}_{2}$ & $\mathrm{NO}_{x}$ & $\mathrm{O}_{3}$ & $\mathrm{SO}_{2}$ \\
\hline 1. Rognac & 1.68 & 16.10 & 11.15 & 75.81 & 15.95 \\
2. Sausset-les-pins & 1.04 & 10.30 & 8.34 & 81.71 & 19.30 \\
3. Martigues & 1.43 & 12.04 & 9.95 & 87.23 & 12.05 \\
4. Port de bouc & 16.02 & 37.12 & 39.50 & 73.50 & 16.62 \\
5. St. Martin de Crau & 7.65 & 19.08 & 20.82 & 62.65 & 8.31 \\
6. St. Rémy de Provence & 4.34 & 4.38 & 6.76 & 75.25 & 1.18 \\
7. Luberon & 0.08 & 0.66 & 3.94 & 110.15 & 0.74 \\
\hline
\end{tabular}


second was performed with ratios simple phenol/total phenol and atmospheric pollutant concentrations: 42 points ( 6 individuals, 7 stations) and 6 variables. From the PCAs, two hierarchical classifications were determined.

\section{Results}

For each pollutant, the seven sites differed statistically in atmospheric pollutant concentrations $(P<$ $0.01)$. These stations were influenced by one or more pollutants (Table 1). Port de Bouc (4) was marked by high levels of nitric oxide, nitrogen dioxide, nitrogen oxides and sulphur dioxide. Sulphur dioxide was found in high concentrations at the study sites located closest to the Berre lagoon: Sausset-les-pins (2), Rognac (1) and Martigues (3). The highest ozone concentrations were recorded in the Luberon (7). St. Martin de Crau (5) had moderate concentrations in nitric oxide, nitrogen dioxide and nitrogen oxides. The lowest concentrations of atmospheric pollutant were encountered at St. Rémy de Provence (6). As the latter exhibits the lowest level of the total pollution, it may be considered as the control study site. Indeed, this study site is the farest site from the most significant sources of air pollution in this area, like industrial activity and road traffic.

Total phenol content varied significantly in Aleppo pine needles according to the study sites $(P<0.05$; Fig. 2). St. Rémy de Provence (6) presented the lowest concentrations and Sausset-les-Pins (2) the highest. There was a significantly negative correlation between total phenolic content and the nitric oxide concentrations $(P<0.01)$ and a significantly positive correlation be-

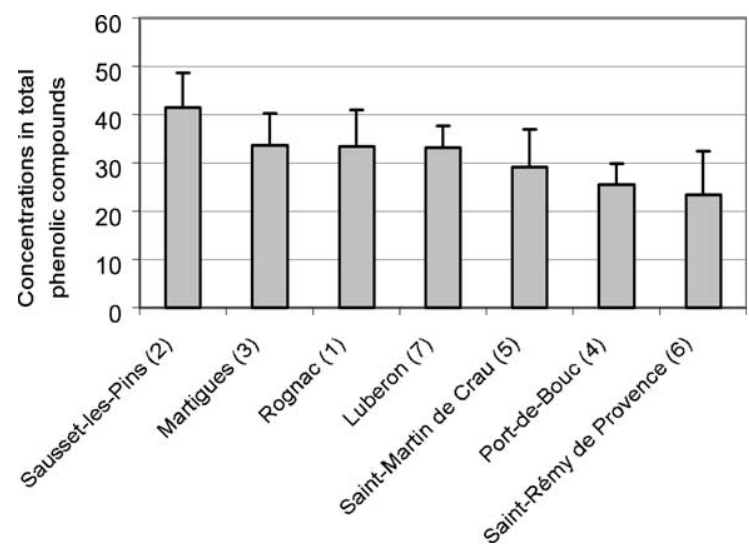

Fig. 2. Average concentrations in total phenolic compounds in the needles of Aleppo pine ( $\mathrm{mg}$ of gallic acid/g of dry matter \pm standard deviation), for the various sites.

tween total phenolics and sulphur dioxide concentrations $(P<0.05)$.

A two-dimensional mapping of the PCA is presented in Fig. 3. Axis 1, representing $60.2 \%$ of the data, is characterized on the positive side by ozone concentrations and on the negative side by nitric oxide, nitrogen dioxide and nitrogen oxide concentrations. Axis 2, representing $23.4 \%$ of the data, was characterized on the positive side by total phenol concentrations. The distribution of the point-individuals in the two-dimensional mapping shows a homogeneity between individuals at the same study site. The ascending hierarchical clustering statistically differentiated four main site groups. The first includes Port de Bouc (4) individuals. This site is strongly influenced by very high levels of nitric oxide,

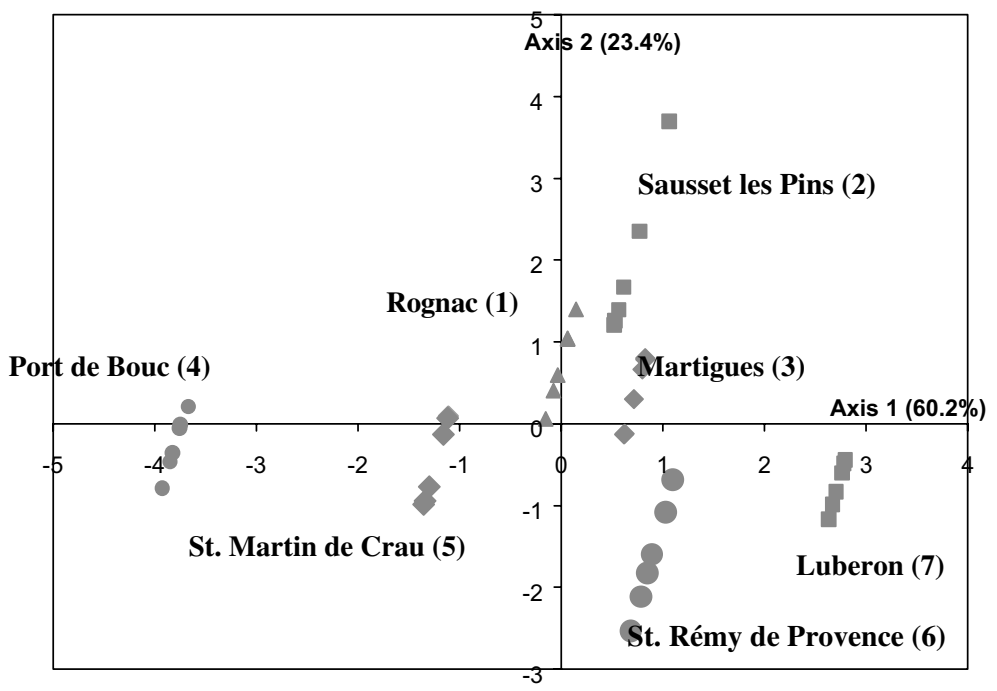

Fig. 3. Two-dimensional mapping of PCA performed on total phenols and atmospheric pollutants. 
nitrogen dioxide and nitrogen oxides and individuals are characterized by low total phenolics concentrations. The second group includes the individuals from Saussetles-Pins (2), Martigues (3) and Rognac (1) showing relatively high total phenolic content and significant sulphur dioxide levels. The third group includes the individuals from the Luberon (7). This site is influenced by very high ozone concentrations and individuals are characterized by intermediate total phenolics concentrations. The last group includes the individuals from the two least polluted sites: St. Martin de Crau (5) and St. Rémy de Provence (6). These individuals are characterized by the lowest phenolic content.

Seven major simple phenolics were identified and quantified: gallic acid, protocatechuic acid, 4-hydroxybenzoic acid, vanillic acid, syringic acid, $p$-coumaric acid and vanillin (Fig. 4). They represent more than $67.7 \%$ of all the compounds present on the chromatograms (for the whole set of study sites). Protocatechuic acid was found in large quantities with an average of $54.7 \mu \mathrm{g} / \mathrm{g}$ of dry matter (Fig. 4). Vanillic acid was present in lower concentrations but with more than $10 \mu \mathrm{g} / \mathrm{g}$ of dry matter. The other compounds were found in much smaller quantities, with concentrations lower than $9 \mu \mathrm{g} / \mathrm{g}$ of dry matter (Fig. 4).

Mean concentrations of simple phenols for each study site are presented in Table 2 . We normalised the simple phenols to total phenols to minimize the variations of total phenols contents probably due to differences in biological activity or physiological condition. Ratios "concentrations of the simple phenolic compounds/concentrations total phenolic compounds" are presented in Table 3. The correlation matrix shows significantly positive relations between the nitric oxide, nitrogen dioxide, nitrogen oxides and $p$-coumaric acid, syringic acid and 4-hydroxybenzoic acid $(P<0.01)$. Significantly negative relations were found between gallic acid and sulphur dioxide $(P<0.05)$ and between ozone and vanillin $(P<0.05)$.

A two-dimensional mapping of the PCA is presented in Fig. 5. Axis 1, representing $48.9 \%$ of the data, is characterized on the negative side by 4-hydroxybenzoic acid, vanillic acid, vanilline, syringic acid and $p$-coumaric acid concentrations. Axis 2, representing 26.8\% of the data, is characterized on the positive side by sulphur dioxide, nitrogen dioxide, nitrogen oxides and nitric

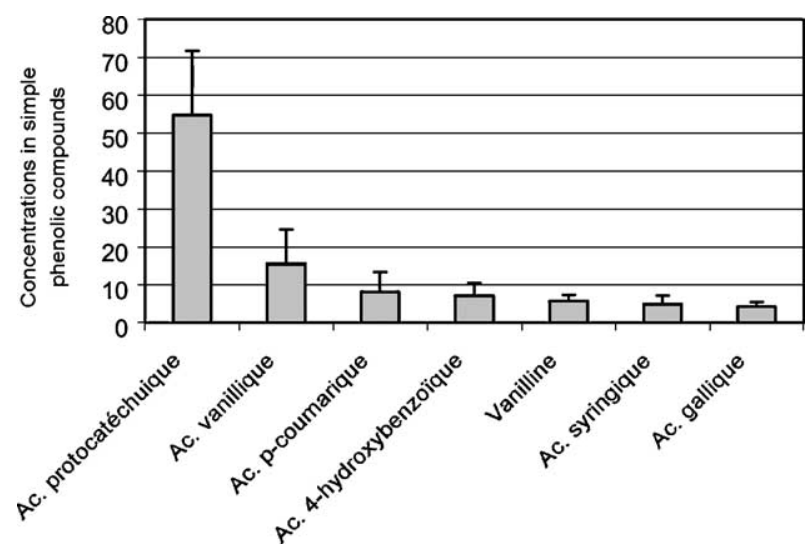

Fig. 4. Average concentrations in simple phenolic compounds in the needles of Aleppo pine ( $\mu \mathrm{g} / \mathrm{g}$ of dry matter \pm standard deviation), all stations together.

Table 2

Average concentrations of the simple phenolic compounds ( $\mu \mathrm{g} / \mathrm{g}$ of dry matter \pm standard deviation) by site

\begin{tabular}{|c|c|c|c|c|c|c|c|}
\hline & Rognac (1) & $\begin{array}{l}\text { Sausset- } \\
\text { les-Pins (2) }\end{array}$ & Martigues (3) & $\begin{array}{l}\text { Port de Bouc } \\
\text { (4) }\end{array}$ & $\begin{array}{l}\text { St. Martin de } \\
\text { Crau (5) }\end{array}$ & $\begin{array}{l}\text { St. Rémy de } \\
\text { Provence (6) }\end{array}$ & Luberon (7) \\
\hline $\begin{array}{l}\text { Protocatechuic } \\
\text { acid }\end{array}$ & $71.26 \pm 21.47$ & $39.78 \pm 12.68$ & $46.29 \pm 19.94$ & $52.24 \pm 16.52$ & $54.83 \pm 10.57$ & $63.59 \pm 9.36$ & $55.41 \pm 10.62$ \\
\hline Vanillic acid & $11.12 \pm 1.89$ & $8.36 \pm 2.80$ & $20.26 \pm 7.60$ & $24.09 \pm 7.60$ & $9.88 \pm 3.31$ & $22.26 \pm 15.05$ & $12.56 \pm 4.45$ \\
\hline$p$-Coumaric acid & $5.37 \pm 0.69$ & $4.59 \pm 1.55$ & $7.52 \pm 2.47$ & $17.68 \pm 4.05$ & $5.98 \pm 2.06$ & $10.20 \pm 6.29$ & $5.60 \pm 1.32$ \\
\hline $\begin{array}{l}\text { 4-Hydroxybenzoic } \\
\text { acid }\end{array}$ & $5.74 \pm 1.20$ & $4.50 \pm 1.08$ & $8.83 \pm 3.38$ & $11.70 \pm 1.69$ & $5.16 \pm 1.31$ & $8.35 \pm 4.51$ & $5.49 \pm 2.02$ \\
\hline Vanilline & $5.63 \pm 1.02$ & $3.70 \pm 0.65$ & $6.90 \pm 0.31$ & $6.13 \pm 1.03$ & $6.59 \pm 1.09$ & $6.92 \pm 0.78$ & $4.68 \pm 1.34$ \\
\hline Syringic acid & $4.09 \pm 0.40$ & $4.08 \pm 1.50$ & $6.35 \pm 2.24$ & $7.63 \pm 2.61$ & $3.52 \pm 0.97$ & $5.54 \pm 2.27$ & $2.90 \pm 0.84$ \\
\hline Gallic acid & $4.81 \pm 1.07$ & $2.96 \pm 0.85$ & $4.12 \pm 0.60$ & $4.15 \pm 1.27$ & $4.05 \pm 0.73$ & $5.30 \pm 1.36$ & $4.41 \pm 0.79$ \\
\hline
\end{tabular}


Table 3

Ratio of "concentrations of the simple phenolic compounds/concentrations total phenolic compounds" by site $\left(\times 10^{-3}\right)$

\begin{tabular}{|c|c|c|c|c|c|c|c|}
\hline & Rognac (1) & $\begin{array}{l}\text { Sausset-les- } \\
\text { Pins (2) }\end{array}$ & Martigues (3) & $\begin{array}{l}\text { Port de Bouc } \\
\text { (4) }\end{array}$ & $\begin{array}{l}\text { St. Martin de } \\
\text { Crau (5) }\end{array}$ & $\begin{array}{l}\text { St. Rémy de } \\
\text { Provence (6) }\end{array}$ & Luberon (7) \\
\hline $\begin{array}{l}\text { Protocatechuic } \\
\text { acid }\end{array}$ & $2.15 \pm 0.55$ & $0.95 \pm 0.18$ & $1.49 \pm 0.82$ & $2.06 \pm 0.69$ & $1.94 \pm 0.84$ & $2.99 \pm 0.98$ & $1.70 \pm 0.35$ \\
\hline Vanillic acid & $0.35 \pm 0.13$ & $0.20 \pm 0.06$ & $0.66 \pm 0.34$ & $0.97 \pm 0.40$ & $0.33 \pm 0.08$ & $1.15 \pm 0.98$ & $0.39 \pm 0.14$ \\
\hline$p$-Coumaric acid & $0.17 \pm 0.07$ & $0.11 \pm 0.02$ & $0.25 \pm 0.13$ & $0.71 \pm 0.22$ & $0.20 \pm 0.08$ & $0.54 \pm 0.44$ & $0.17 \pm 0.03$ \\
\hline $\begin{array}{l}\text { 4-Hydroxybenzoic } \\
\text { acid }\end{array}$ & $0.18 \pm 0.04$ & $0.11 \pm 0.02$ & $0.29 \pm 0.16$ & $0.47 \pm 0.12$ & $0.19 \pm 0.09$ & $0.44 \pm 0.33$ & $0.17 \pm 0.06$ \\
\hline Vanilline & $0.18 \pm 0.08$ & $0.09 \pm 0.02$ & $0.22 \pm 0.05$ & $0.24 \pm 0.04$ & $0.23 \pm 0.07$ & $0.34 \pm 0.17$ & $0.14 \pm 0.03$ \\
\hline Syringic acid & $0.13 \pm 0.05$ & $0.10 \pm 0.03$ & $0.21 \pm 0.11$ & $0.30 \pm 0.12$ & $0.13 \pm 0.06$ & $0.27 \pm 0.15$ & $0.09 \pm 0.02$ \\
\hline Gallic acid & $0.15 \pm 0.03$ & $0.07 \pm 0.01$ & $0.13 \pm 0.03$ & $0.16 \pm 0.03$ & $0.14 \pm 0.06$ & $0.25 \pm 0.11$ & $0.13 \pm 0.02$ \\
\hline
\end{tabular}

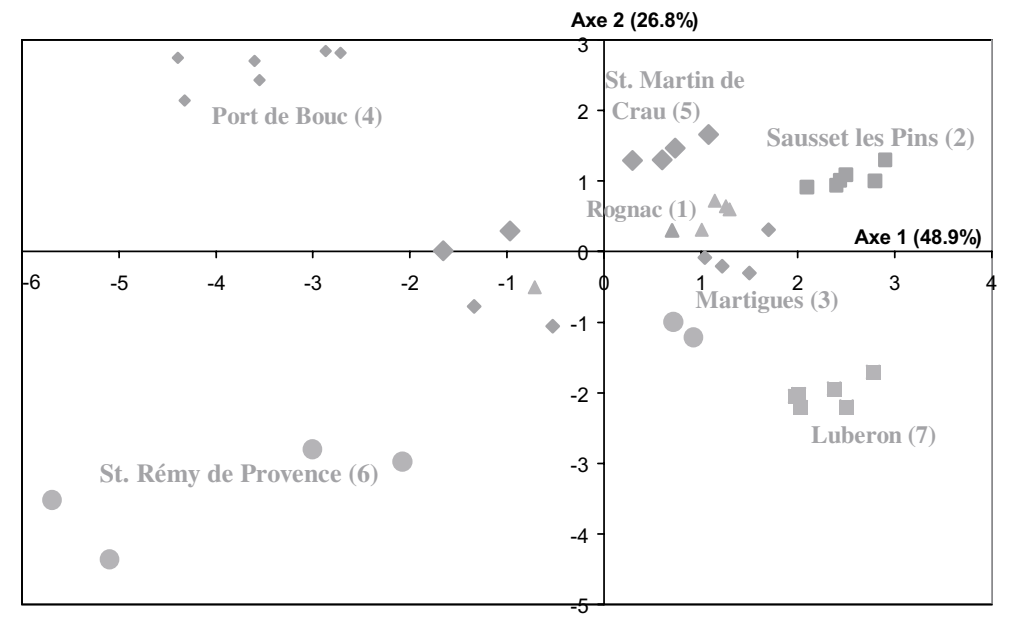

Fig. 5. Two-dimensional mapping of PCA performed on ratio simple phenols/total phenols and atmospheric pollutants.

oxide concentrations and on the negative side by gallic acid. The distribution of the point-individuals in the two-dimensional mapping shows a relatively homogeneity between individuals at the same study site. The ascending hierarchical clustering statistically differentiated five main site groups. The first includes Port de Bouc (4) individuals. This site is strongly influenced by very high levels of nitric oxide, nitrogen dioxide and nitrogen oxides and individuals are characterized by strong 4-hydroxybenzoic acid, vanillic acid, vanilline, syringic acid and $p$-coumaric acid concentrations. The second group includes Luberon (7) individuals. This site is characterized by low levels of sulphur dioxide, nitrogen dioxide, nitrogen oxides and nitric oxide and by strong gallic acid concentrations. The third group includes the three individuals from St. Rémy de Provence (6) showing strong levels of 4-hydroxybenzoic acid, vanillic acid, vanilline, syringic acid, $p$-coumaric acid and gallic acid. The fourth group includes the individuals from Sausset-les-Pins (2) and few individuals from
Martigues (3) and Rognac (1) showing low levels of 4hydroxybenzoic acid, vanillic acid, vanilline, syringic acid, $p$-coumaric acid and gallic acid. This site shows a high sulphur dioxide levels. The last group includes the few individuals from Martigues (3), Rognac (1), St. Rémy de Provence (6) and all the individuals from St. Martin de Provence (5).

\section{Discussion}

Plants integrated many environmmmental parameters and represented useful tools to show environmental problems revealing the dysfunctioning of the ecosystems (Godefroid, 2001). Many examples are reported where plant bioindicators have been used to assess environmental pollution by their presence or absence or the description of their visual symptoms. Changements in physiological and biochemical parameters have been recently developed because they may be used as an early 
test to detect the first stages of pollution before the appearance of any visual signs of damage (Contour-Ansel and Louguet, 1986).

Quantities of total phenolics in P. halepensis needles ranged from 23 to $41 \mathrm{mg}$ of gallic acid/g of dry matter. Other species of the same genus, also exposed to air pollution, such as Pinus nigra (Giertych et al., 1999), Pinus sylvestris (Karolewski, 1990) and Pinus eldarica (Peñuelas et al., 1996) presented similar quantities. The reaction of $P$. halepensis appears to be comparable to those of other species.

Atmospheric pollution level may be considered as a constant during the whole year with a slightly increase during summer and winter dry seasons (AIRFOBEP, 2000). So, the monitoring of air pollutants during the study period is confirmed by long term records of air pollution on these sites. A direct dose-effect relationship between air pollutants concentrations and phenol contents may be assumed. However, other environmental factors can lead variations of phenol contents (eg. the temperature). That is the reason why the sites have been chosen in a non-extended area.

The positive correlation between total phenols and sulphur dioxide indicates that high sulphur dioxide concentration induces high total phenolics content in plants. Thus, Sausset-les-Pins (2) individuals exposed to the highest sulphur dioxide concentrations presented the most significant quantity of total phenols in $P$. halepensis needles. St. Rémy de Provence (6), which is characterized by very low sulphur dioxide levels, presented the lowest total phenolics contents (Fig. 2). Similar results have been obtained on $P$. sylvestris in pollutioncontrolled environment experiments (Karolewski, 1990; Giertych and Karolewski, 1993) and in a natural environment (Karolewski and Giertych, 1995), and even for a very different species such as Vicia faba (Nandi et al., 1990). Strong sulphur dioxide levels induced an increase in necroses, a reduction in breathing and other vital dysfunctions (Pierre and Queiroz, 1981; Nandi et al., 1990). Thus, these alterations supported and facilitated the biosynthesis of phenols, because it seems that these compounds play a role in breathing (Rubin and Arcichowska, 1971 in Giertych et al., 1999).

No significant correlations have been found between ozone and total phenol concentrations. However, PCA results indicated a slight increase in total phenolics for ozone-exposed trees. Individuals from the Luberon (7), a study site distinguished by high ozone levels and low concentrations in other pollutants, presented a mean content in total phenols higher than that of St. Rémy de Provence (6), considered as the control site (Figs. 2 and $3)$. Very few studies have been carried out on the impact of ozone in controlled environment (Howell, 1970; Louguet et al., 1989; Langebartels et al., 1990; Kainulainen et al., 1994). According to Howell (1970), high ozone level influenced enzymatic activity intervening in phenol metabolism. Langebartels et al. (1990) showed an increase in phenolic compounds with ozone-exposed plants. However, according to Kainulainen et al. (1994), there was no relation between total phenol concentrations and high ozone concentrations. Ozone impact on total phenol concentrations has given rise to many contradictory results and may be dependent on the species. For P. halepensis, Anttonen et al. (1995) and Pelloux et al. (2001) clearly showed that ozone induced a decrease in chlorophyl content and an increase in necrosis, as well as carbon metabolism alterations. However, the high total phenol concentrations for individuals located at the Luberon site (7) may also be related to the impact of other environmental factors.

Our results show a significantly negative correlation between total phenolics and nitrogen oxide concentrations (nitrogen dioxide and nitric oxide included). The Porc de Bouc site (4), which presented the highest levels of nitrogenized pollutants, was clearly distinguished from the other sites (Fig. 3), with very low total phenolic concentrations (Fig. 2). This negative correlation between nitrogen oxides and total phenolics may be explained by the positive impact of these pollutants on the activity of nitrate reductase (Krywult et al., 1996). This enzyme promotes nitrogen assimilation and several studies have shown negative correlations between nitrogen and phenolic compound concentrations in needles or leaves of various species (Giertych et al., 1999).

Visual foliar injuries have been reported for air pollutants on several plant species. Tipburn and chlorotic mottling are thought to be manifestations of visible symptoms of $\mathrm{SO}_{2}$ injury in Conifers. They are not especially specific and appear also with $\mathrm{O}_{3}$ injury (Manninen et al., 1996). $\mathrm{SO}_{2}$ and $\mathrm{NO}_{2}$ may have an effect on needles surface waxes inducing wax degradation and needle surface erosion (Grodzinska-Jurczak and SzarekLukaszewska, 1999). Gaseous pollutants enter through stomata and cause alterations first in the extracellular aqueous phase and later in cell membranes and, further, intracellular structures. So many of the morphological and anatomical damages can be described as a multistress symptom caused by several pollutants (Rautio et al., 1998).

The use of simple phenols as biological indicators of air pollution had never been researched before the recent study by Loponen et al. (2001) on Betula pubescens ssp. Czerepanovii for air heavy metal pollution. No comparable study has been carried out on Pinus species. However, numerous allelopathic research investigations have allowed identification of simple phenolic compounds from other species of the genus Pinus. All simple phenols indentified in $P$. halepensis needles in this study have been found in other species such as $P$. sylvestris (Kuiters and Sarink, 1986) or Pinus radiata (Souto et al., 1994). Quantitatively, P. halepensis presented phenol concentrations approximately five times lower than 
those of P. sylvestris (Kuiters and Sarink, 1986). These differences may be explained by distinct environmental conditions and by a characteristic metabolism for each species.

Correlations between air pollutants and simple phenol concentrations (or ratios) and PCA showed concordant results. $p$-Coumaric acid, syringic acid and 4-hydroxybenzoic acid concentrations increase with exposure to nitrogen oxide pollution, whereas gallic acid and vanillin decrease in the presence respectively of sulphur dioxide and ozone.

The cinnamic acid, synthetized via the shikimic acid pathway, is the common precursor of phenolic compounds. Aromatic hydroxylation of cinnamic acid leads to $p$-coumaric acid. Shortening of the side chain of cinnamic acid by $\beta$-oxydation, followed by aromatic hydroxylation, is one of the main routes leading to benzoic acids. A second aromatic hydroxylation leads to protocatechuic acid and, after a methyletion, to vanillic acid. Vanillic acid may be also obtained via $p$-coumaric acid pathways. Methoxylation of vanillic acid is one route leading to syringic acid (Torssell, 1981). Several enzymes, which take part in these biosynthetic pathways, may be more sensitive than others in relation to different pollutants (Loponen et al., 2001). So, impacts of pollutants on plant secondary metabolism depend on chemical nature of pollutant and also, on plant species because metabolic pathways of secondary compounds vary according to the plant species. For example, ozone exposure is known to alter the activity of phenylalanine ammonia lyase and chalcone synthetase which regulate synthesis of phenolic compounds. However, Lindroth et al. (2001) have shown that $\mathrm{O}_{3}$ fumigation did not influence phenolic compounds levels in Populus tremuloides and Betula papyrifera. The accumulation of total and simple phenols in $P$. halepensis needles indicates activation of shikimate pathway under air pollution.

This in situ work confirms the interest of using total phenolic compounds of $P$. halepensis needles as biological indicators of air quality. The use of total phenolics as biological indicators would appear to be of use for the assessment of sulphur dioxide and nitrogen oxides pollution. Simple phenolics constitute valuable bioindicators for nitrogen oxide, sulphur dioxide and ozone pollution.

The majority of phenolic compounds taken into account in this study responded to the impact of several atmospheric pollutants. While they did not make it possible to precisely characterize the level of a given pollutant, they showed the total degree of pollution of a site and thus constitute an interesting method for air pollution monitoring. Other researches will be performed to characterize the level of a given pollutant, and to check these first field results.

\section{Acknowledgements}

This study has been financed by the Région Provence-Alpes-Côtes d'Azur and by the AIRFOBEP (organization responsible for air quality monitoring in this area). We thank M. Paul for kindly proof-reading the manuscript.

\section{References}

AIRFOBEP, 2000. Qualitéde l'air de la region de l'étang de Berre et de l'Ouest des bouches-du-Rhône. Bilan de la période 1998/1999. AIRFOBEP Publishers, France.

Alaimo, M.G., Dongarra, G., Melati, M.R., Monna, F., Varrico, D., 2000. Recognition of environmental trace metal contamination using pine needles as bioindicators. The urban area of Palermo (Italy). Environ. Geol. 39 (8), 914-924.

Anttonen, S., Herranen, J., Peura, P., Kärenlampi, L., 1995. Fatty acids and ultrastructure of ozone-exposed Aleppo pine (Pinus halepensis Mill.) needles. Environ. Pollut. 87, 235-242.

Beart, J.E., Lilley, T.H., Haslam, E., 1985. Plant polyphenols secondary metabolism and chemical defence: some observations. Phytochemistry 24 (1), 33-38.

Bortnick, S.M., Stetzer, S.L., 2002. Sampling frequency guidance for ambient air toxics monitoring. J. Air Waste Manag. Assoc., July, 867-876.

Chappelka, A., Somers, G., Renfro, J., Sheppard, L.J., Cape, J.N., 1999. Visible ozone injury on forest trees in Great Smoky Mountains National park, USA. Forest Growth Responses to the Pollution Climate of the 21st Century. Water, Air Soil Pollut. 116 (1-2), 255-260.

Conti, M.E., Cecchetti, G., 2001. Biological monitoring: lichens as bioindicators of air pollution assessment-a review. Environ. Pollut. 114, 471-492.

Contour-Ansel, D., Louguet, P., 1986. Variation du taux de polyphénols dans les aiguilles d'épicéas (Picea abies), présentant differents degrés de dépérissement. Pollut. Atmos., October-December, 270-274.

Cooper-Driver, G., Bhattacharya, M., 1998. Role of phenolics in plant evolution. Phytochemistry 49 (5), 1165-1174.

Giertych, M.J., Karolewski, P., 1993. Changes in phenolic compounds content in needles of scots pine (Pinus sylvestris L.) seedlings following short term exposition to sulphur dioxide. Arboretum Kornickie 38, 43-51.

Giertych, M.J., Karolewski, P., De Temmerman, L.O., 1999. Foliage age and pollution alter content of phenolic compounds and chemical elements in Pinus nigra needles. Water, Air Soil Pollut. 110, 363-377.

Godefroid, S., 2001. Temporal analysis of the Brussels flora as indicator for changing environmental quality. Landscape and Urban Planning 52, 203-224.

Grodzinska-Jurczak, M., Szarek-Lukaszewska, G., 1999. Evaluation of $\mathrm{SO}^{2}$ and $\mathrm{NO}^{2}$ related degradation of coniferous forest stands in Poland. The Sci. Total Environ. 241, 1-15.

Hagerman, A.E., Robbins, C.T., 1987. Implications of soluble tannin-protein complexes for tannin analysis and plant defense mechanisms. J. Chem. Ecol. 13 (5), 1243-1259. 
Haslam, E., 1989. Plant Polyphenols. University Press Publishers, Cambridge.

Hawksworth, D.L., Rose, F., 1970. Qualitative scale for estimating sulfur dioxide air pollution in England and Wales using epiphytic lichens. Nature 227, 145-148.

Howell, R.K., 1970. Influence of air pollution on quantities of caffeic acid isolated from leaves of Phaseolus vulgaris. Phytopathology 60 (11), 1626-1629.

Ibald-Mulli, A., Stieber, J., Wichmann, H., Koenig, W., Peters, A., 2001. Effects of air pollution on blood pressure: a population-based approach. Am. J. Public Health 91 (4), 571-577.

Kainulainen, P., Holopainen, J.K., Hyttinen, H., Oksanen, J., 1994. Effect of ozone on the biochemistry and aphid infestation of scots pine. Phytochemistry 35 (1), 39-42.

Karlsson, G.P., Pleijel, H., Sild, E., Danielsson, H., Sellden, G., Ericson, L., Skarby, L., Grennfelt, P., Rohde, H., Thornelof, E., 1995. Clover Sweden: a national three-year study of the effects of tropospheric ozone on Trifolium subterraneum, L.. Water, Air Soil Pollut. 85 (3), 1503-1508.

Karolewski, P., 1990. Visible and invisible injury to scots pine (Pinus sylvestris L.) needles caused by sulphur dioxide. Arboretum Kornickie 35, 127-136.

Karolewski, P., Giertych, M.J., 1994. Influence of toxic metal ions on phenols in needles and roots and on root respiration of scots Pine seedlings. Acta Sociaetatis Botanicorum Poloniae 63 (1), 29-35.

Karolewski, P., Giertych, M.J., 1995. Changes in the level of phenols during needle development in scots-pine populations in a control and polluted environment. Eur. J. For. Path. 25, 297-306.

Krywult, M., Karolak, A., Bytnerowicz, A., 1996. Nitrate reductase activity as an indicator of ponderosa pine response to atmospheric nitrogen deposition in the San Bernardino mountains. Environ. Pollut. 93 (2), 141-146.

Kuiters, A.T., Sarink, H.M., 1986. Leaching of phenolic compound from leaf and needle litter of several decicuous and coniferous trees. Soil Biol. Biochem. 18, 475-480.

Langebartels, C., Heller, W., Kerner, K., Leonardi, S., Rosemann, D., Schraudner, M., Trest, M., Sandermann, H.J., 1990. Ozone-induced defense reaction in plants. Environmental research with plants in closed chambers. Air pollution Research Reports of the EC26. EEC, Brussels, pp. 358-368.

Lindroth, R.L., Kopper, B.J., Parson, F.J., Bockheim, J.G., Karnosky, D.F., Hendrey, G.R., Pregitzer, K.S., Isebrand, J.G., Sober, J., 2001. Consequences of elevated carbon dioxide and ozone for foliar chemical composition and dynamics in trembling aspen (Populus tremuloides) and paper birch (Betula papyrifera). Environ. Pollut. 115, 395404.

Loponen, J., Lempa, K., Ossipov, V., Kozloov, M.V., Girs, A., Hangasmaa, K., Haukioja, E., Pihlaja, K., 2001. Patterns in content of phenolic compounds in leaves of mountain birches along a strong pollution gradient. Chemosphere 45 , 291-301.

Louguet, P., Malka, P., Contour-Ansel, D., 1989. Etude comparée de la résistance stomatique et de la teneur en composés phénoliques foliaires chez trois clones d'Epicéas soumis à une pollution contrôlée par l'ozone et le dioxyde de soufre en chambre à ciel ouvert. In: Brasser, T.J., Mulde, W.C. (Eds.). Man and his ecosystem. Proceedings of the 8th World Clean Air Congress, 11-15 September 1989, The Hague, Elsevier, pp. 73-78.

Macheix, J.J., 1996. Les composés phénoliques des végétaux: quelles perspectives à la fin du XXème siècle? Acta Bot. Gallica 143 (6), 473-479.

Manninen, S., Huttunen, S., Rautio, P., Perämäki, P., 1996. Assessing the critical level of $\mathrm{SO}^{2}$ for Scots pine in situ. Environ. Pollut. 93, 27-38.

Monna, F., Aiuppa, A., Varrica, D., Dongarra, G., 1999. Pb isotope composition in lichens and aerosols from eastern Sicily: insights into the regional impact of volcanoes on the environment. Environ. Sci. Technol. 33, 2517-2523.

Muzika, R.M., 1993. Terpenes and phenolics in response to nitrogen fertilization: a test of carbon/nutrient balance hypothesis. Chemoecology 4 (1), 3-7.

Nandi, P.K., Madhoolika, A., Agrawal, M., Agrawal, S.B., Rao, D.N., 1990. Physiological responses of Vicia faba to sulfur dioxide. Ecotox. Environ. Safety 19, 64-71.

Oleksyn, J., Reich, P.B., Karolewski, P., Tjoelker, M.G., Chalupka, W., 1999. Nutritional status of pollen and needles of diverse Pinus sylvestris populations grown at sites with contrasting pollution. Water, Air Soil Pollut. 110 (1-2), 195-212.

Omasa, K., Youssefian, S., Kondo, N., 2002. Air pollution and plant biotechnology: prospects for phytomonitoring and phytoremediation. Springer Publishers, New York.

Pelloux, J., Jolivet, Y., Fontaine, V., Banvoy, J., Dizengremel, P., 2001. Changes in RuBisCo en rubisco activase gene expression and polypeptide content in Pinus halepensis Mill. subjected to ozone and drought. Plant. Cell Environ. 24 (1), 123-131.

Peñuelas, J., Estiarte, M., Kimball, B.A., Idso, S.B., Pinter, P.J., Wall, G.W., Garcia, R.L., Hansaker, D.J., LaMorte, R.L., Hendrix, D.L., 1996. Variety of responses of plant phenolic concentration to $\mathrm{CO}_{2}$ enrichment. J. Expt. Bot. 47 (302), 1463-1467.

Pierre, M., Queiroz, O., 1981. Enzymic and metabolic change$\sin$ bean leaves during continuous pollution by subnecrotic levels of $\mathrm{SO}_{2}$. Environ. Pollut. 25, 41-51.

Pisani, J.M., Distel, R.A., 1998. Inter and intraspecific variations in production of spines and phenols in Prosopis caldemia and Prosopis flexuosa. J. Chem. Ecol. 24 (1), 23-36.

Rautio, P., Huttunen, S., Kukkola, E., Peura, R., Lamppu, J., 1998. Deposited particles, element concentrations and needle injuries on Scots pines along an industrial pollution transect in northern Europe. Environ. Pollut. 103, 81-89.

Rhodes, M.J.C., 1994. Physical role for secondary metabolites in plants: some progress, many outstanding problems. Plant Mol. Biol. 24, 1-20.

Seaward, M.R.D., 1993. Lichens and sulphur dioxide air pollution: field studies. Environ. Rev. 1, 73-91.

Souto, X.C., Gonzalez, L., Reigosa, M.J., 1994. Comparative analysis of allelopathic effects produced by four forestry species during decomposition process in their soils in Galicia (NW Spain). J. Chem. Ecol. 20 (11), 3005-3015.

Spaink, H.P., 1998. Flavonoids as regulators of plant development. New insights from studies of plant-rhizobia interactions. In: Romeo, J.T. et al. (Eds.), Phytochemical Signals 
and Plant-microbe Interactions. Plenum Press Publishers, New York, pp. 167-177.

Torssell, K.B.G., 1981. Natural product chemistry. In: A mechanistic and biosynthetic approach to secondary metabolism. J. Wiley \& Sons Publishers, New-York.
Waterman, P.G., Mole, S., 1994. Analysis of Phenolic Plant Metabolites. Blackwell Scientific Publishers, New York.

White, C.S., 1994. Monoterpenes: their effects on ecosystem nutrient cycling. J. Chem. Ecol. 20 (6), 1381-1406. 